\title{
Phytotoxicity of silver nanoparticles to cucumber (Cucumis sativus) and wheat (Triticum aestivum)*
}

\author{
Di CUI ${ }^{\dagger \$ 1,2}$, Peng ZHANG ${ }^{\dagger \S 1}$, Yu-hui MA ${ }^{1}$, Xiao HE ${ }^{1}$, Yuan-yuan $\mathrm{LI}^{1}$, \\ Yue-chun ZHAO ${ }^{\dagger \ddagger 2}$, Zhi-yong ZHANG ${ }^{\dagger 1}$ \\ ('Key Laboratory for Biological Effects of Nanomaterials and Nanosafety, Key Laboratory of Nuclear Radiation and Nuclear Energy Technology, \\ Institute of High Energy Physics, Chinese Academy of Sciences, Beijing 100049, China) \\ ( ${ }^{2}$ Department of Applied Chemistry, College of Science, South China Agricultural University, Guangzhou 510642, China) \\ †E-mail: yczhao@scau.edu.cn; zhangzhy@ihep.ac.cn \\ Received Apr. 30, 2014; Revision accepted July 10, 2014; Crosschecked July 25, 2014
}

\begin{abstract}
The increasing release of silver (Ag) nanoparticles (NPs) into the environment highlights the importance of exploring the interactions between Ag NPs and plants, which are the basis of most ecosystems. In this study, two plant species, Cucumis sativus L. (cucumber) and Triticum aestivum L. (wheat) were exposed to $\mathrm{Ag} \mathrm{NPs}$ and $\mathrm{Ag}^{+}$(added as $\mathrm{AgNO}_{3}$ ) at the germination and vegetative growth stages. Above certain concentrations, $\mathrm{Ag}$ NPs and $\mathrm{Ag}^{+}$were toxic to the two plants. However, stimulatory effects were observed on root elongation for the cucumbers that were exposed to Ag NPs at concentrations below $200 \mathrm{mg} / \mathrm{L}$, and $\mathrm{Ag}^{+}$at concentrations below $5 \mathrm{mg} / \mathrm{L}$. The two plants were more susceptible to the toxicity of $\mathrm{Ag}$ NPs at the vegetative growth stage than the germination stage. Ag was accumulated in the roots and was subsequently translocated to the shoots after the exposure to Ag NPs. To assess the role of released $\mathrm{Ag}^{+}$, we measured the dissolution of Ag NPs in exposure solutions. About $0.03 \%$ and $0.01 \%$ of Ag NPs were dissolved into a hydroponic solution at the germination stage for cucumber and wheat, respectively; while $0.17 \%$ and $0.06 \%$ at the vegetative period for cucumber and wheat, respectively. Cysteine, a strong chelating ligand of $\mathrm{Ag}^{+}, \mathrm{could}$ completely eliminate the effects of Ag NPs on cucumber and wheat, suggesting that the phytotoxicity of Ag NPs was possibly caused by the release of $\mathrm{Ag}^{+}$.
\end{abstract}

Key words: Silver nanoparticles, $\mathrm{Ag}^{+}$, Cucumis sativus L., Triticum aestivum L., Phytotoxicity doi:10.1631/jzus.A1400114

Document code: A

CLC number: Q945.78

\section{Introduction}

Silver (Ag) nanoparticles (NPs) are increasingly used for their antimicrobial properties in household antiseptic sprays, food packaging, and antimicrobial coatings of medical devices and clothes (Benn and Westerhoff, 2008; Blaser et al., 2008). Ag is consid-

\footnotetext{
${ }^{\ddagger}$ Corresponding authors

${ }^{\S}$ The two authors contributed equally to this work

* Project supported by the National Key Basic Research Program of China (Nos. 2011CB933400 and 2013CB932703), the Special Fund for the Public Interest Research of China (No. 201209012), and the National Natural Science Foundation of China (Nos. 11275215, 11275218, and 11375009)

(c) Zhejiang University and Springer-Verlag Berlin Heidelberg 2014
}

ered to be one of the most toxic trace metals (Ratte 1999), and the widespread use of Ag NPs has increased the likelihood of releases into the environment, which underscores the need to assess the impacts of Ag NPs on the ecosystem's health. Ag NPs are reported to be potentially toxic to bacteria (Morones et al., 2005), algae (Miao et al., 2010), human cells (Jiang et al., 2008; AshaRani et al., 2009), and animal cells (Hussain et al., 2005). Although much evidence has shown that both $\mathrm{Ag}$ NPs and $\mathrm{Ag}^{+}$ are toxic, it is unclear whether the toxicity is specifically related to NPs or dissolved forms of $\mathrm{Ag}$ from $\mathrm{Ag}$ NPs. Choi and Hu (2008) reported that Ag NPs less than $5 \mathrm{~nm}$ were more toxic to nitrifying bacteria than dissolved $\mathrm{Ag}$ or larger $\mathrm{Ag} \mathrm{NPs}$ at similar mass 
concentrations. Yin et al. (2011) showed that the growth inhibition of gum arabic-coated Ag NPs on $L$. multiflorum was higher compared with the same concentration of $\mathrm{Ag}^{+}$and $\mathrm{Ag}$ NPs which could exert direct toxic effects without dissolution. However, $\mathrm{Ag}^{+}$ released from Ag NPs was reported to inhibit respiratory enzymes and induce oxidative stress through the generation of reactive oxygen species (ROS) (Kim et al., 2009). Miao et al. (2009) found that Ag NPs could inhibit the cell growth, photosynthesis, and chlorophyll production of Thalassiosira weissflogii. These toxic effects were from the released $\mathrm{Ag}^{+}$, which suggested that toxicity was mainly due to the presence of dissolved Ag.

Plants are the backbone of all life on earth and are an essential resource for human well-being. In the present study, we comparatively investigated the impacts of uncoated $\mathrm{Ag} \mathrm{NPs}$ and $\mathrm{AgNO}_{3}$ on two agriculturally significant plants, Cucumis sativus L. (cucumber) and Triticum aestivum L. (wheat), at the germination and vegetative growth stages to reveal their phytotoxicities.

\section{Materials and methods}

\subsection{Characterization of Ag NPs}

Uncoated Ag NPs were purchased from SigmaAldrich with the particle size $<100 \mathrm{~nm}$ and purity of $99.5 \%$. The size and morphology were determined by a transmission electron microscope (TEM; JEM200CX, Japan). For TEM sample preparation, a drop of Ag NP suspension (diluted by ethanol) was dripped onto the copper grid after sonication for $30 \mathrm{~min}$. After drying at room temperature, the sample was placed in a specimen holder. Hydrodynamic diameters and zeta potential of Ag NPs were measured by a dynamic light scattering equipment (ZetaSizer 90, Nano series, UK). For the sample preparation, Ag NPs were dispersed in deionized (DI) water and nutrient solution (1/4 strength Hoagland's solution), sonicated for 30 min following by their immediate measurement in a plastic cuvette (path length $1 \mathrm{~cm}$ ). The $\mathrm{pH}$ values of $\mathrm{Ag}$ NP suspensions dispersed in DI water and nutrient solution were 6.9 and 5.5, respectively.

\subsection{Root elongation assay}

Seeds of cucumber and wheat were purchased from the Chinese Academy of Agricultural Sciences and kept in a refrigerator $\left(4{ }^{\circ} \mathrm{C}\right)$ until use. The seeds were pretreated in a $10 \%(\mathrm{v} / \mathrm{v})$ sodium hypochlorite solution for $10 \mathrm{~min}$ and then rinsed for three times with DI water to ensure surface sterility. Different concentrations of Ag NPs were prepared and dispersed by ultrasonic treatment in DI water for $30 \mathrm{~min}$ before use. Then the seeds were soaked in Ag NP suspensions or $\mathrm{AgNO}_{3}$ solutions for $2 \mathrm{~h}$. One piece of filter paper was put into each Petri dish $(100 \mathrm{~mm} \times$ $15 \mathrm{~mm}$ ), and $5 \mathrm{ml}$ of the test solution or suspension was immediately added after ultrasonic treatments. Then 14 seeds were transferred onto each filter paper, and Petri dishes were sealed with parafilm, and placed in the dark under $25^{\circ} \mathrm{C}$ in a climate incubator. After 5-d treatment, the germination was halted. Root lengths were measured with a meter ruler.

\subsection{Biomass assay}

Seeds of cucumber and wheat were germinated on filter papers moistened with DI water at $25{ }^{\circ} \mathrm{C}$ after sterilization and water soaking (Lin and Xing 2007). After $3 \mathrm{~d}$, the uniform seedlings were transplanted into $250 \mathrm{ml}$ beakers containing $100 \mathrm{ml}$ of $1 / 4$ strength Hoagland's solution and each seedling was anchored by plastic foam with a hole in the center. The growth was conducted in a climate incubator for $10 \mathrm{~d}$ at a day/night humidity of $50 \% / 70 \%$, day/night temperature of $27^{\circ} \mathrm{C} / 18{ }^{\circ} \mathrm{C}$, and a $16 \mathrm{~h}$ photoperiod (light intensity of $1.76 \times 10^{4}$ lux) before the phytotoxicity study. Ag NPs with or without cysteine were then added into the nutrient solution followed by ultrasonic pretreatment for $30 \mathrm{~min}$. We tested the effects of Ag NPs alone (1, 5, 20, 50, and $100 \mathrm{mg} / \mathrm{L})$, $100 \mathrm{mg} / \mathrm{L} \mathrm{Ag} \mathrm{NPs}+112 \mathrm{mg} / \mathrm{L}$ cysteine (molar ratio of cysteine:Ag=1:1), and cysteine alone $(112 \mathrm{mg} / \mathrm{L})$ on the growth of the cucumber and wheat seedlings. To maintain a constant volume $(100 \mathrm{ml})$, the solution in each beaker was replenished with fresh nutrient solution every other day. There were six replicates for each treatment. The seedlings were allowed to further grow for three weeks. At the end of the growth period, the seedlings of cucumber and wheat were harvested and washed thoroughly with flowing tap water and DI water. Tissues were collected and biomasses were measured after drying to a constant weight at $70{ }^{\circ} \mathrm{C}$ for $48 \mathrm{~h}$. 


\subsection{Determination of Ag content}

After the above treatments, $\mathrm{Ag}^{+}$concentrations in Ag NP suspensions were measured by an inductively coupled plasma-mass spectrometer (ICP-MS) (Thermo X7, USA) after centrifugation (14000g for $10 \mathrm{~min})$ and ultrafiltration $(0.22 \mu \mathrm{m}$, polyethersulfone resins filter).

The content of $\mathrm{Ag}$ in plant tissues was measured by ICP-MS after $\mathrm{HNO}_{3} / \mathrm{H}_{2} \mathrm{O}_{2}(\mathrm{v} / \mathrm{v}=4: 1)$ digestion on a heating plate. Indium $(100 \mathrm{ng} / \mathrm{ml})$ was used as an internal standard to compensate for signal drifting and matrix suppression. The certified reference material GBW07602 (bush leaves and branches) was digested to examine the recovery. The recovery of $\mathrm{Ag}$ from GBW07602 was 98.9\% and the spike recovery averaged $103 \%$. The relative standard deviation (SD) was $2.3 \%$, and the detection limit was $0.01 \mathrm{ng} / \mathrm{ml}$.

\subsection{TEM examination}

Fresh roots of cucumber and wheat from the control and the treatments of $2000 \mathrm{mg} / \mathrm{L}$ of $\mathrm{Ag}$ NPs after 3-week exposure were observed by TEM to detect if Ag NPs could enter the plant cells. Roots were thoroughly washed with DI water. Samples for TEM were prepared following standard procedures (Bozzola and Russell, 1999). The root apexes (4 mm) were cut and prefixed in $2.5 \%$ glutaraldehyde, washed in a phosphate buffer $(0.05 \mathrm{~mol} / \mathrm{L}, \mathrm{pH} 7.8)$, post-fixed in osmium tetroxide $(10 \mathrm{~g} / \mathrm{L}$ in $0.1 \mathrm{~mol} / \mathrm{L}$ sodium phosphate buffer) for $1 \mathrm{~h}$, dehydrated in graded acetone, and infiltrated and embedded in Spurr's resin. The cross sections (90-nm thick) below root tips were cut for TEM using a UC6i ultramicrotome (Leica, Austria) with a diamond knife. TEM was operated at $80 \mathrm{kV}$ on a JEM-1230. More than $10 \mathrm{sec}-$ tions cut from different roots were examined.

\subsection{Statistical analysis}

Data processing was performed on SPSS V17.0. One-way analysis of variance (ANOVA) followed by Tukey's honestly significant difference (HSD) or Bonferroni test was performed to examine the statistical differences. Data were expressed as mean $\pm \mathrm{SD}$, and $P<0.05$ was considered to be significantly different.

\section{Results and discussion}

\subsection{Characterization of Ag NPs}

The average size of Ag NPs was (13.8 \pm 2.5$) \mathrm{nm}$ according to the TEM image (Fig. 1). The Ag NPs hydrodynamic diameters in the DI water and nutrient solution were $(711.8 \pm 25.3)$ and $(736.4 \pm 32.2) \mathrm{nm}$, respectively. Zeta potentials of the Ag NPs in the DI water and nutrient solution were (4.8 \pm 1.0$)$ and $(-9.6 \pm 0.5) \mathrm{mV}$, respectively.

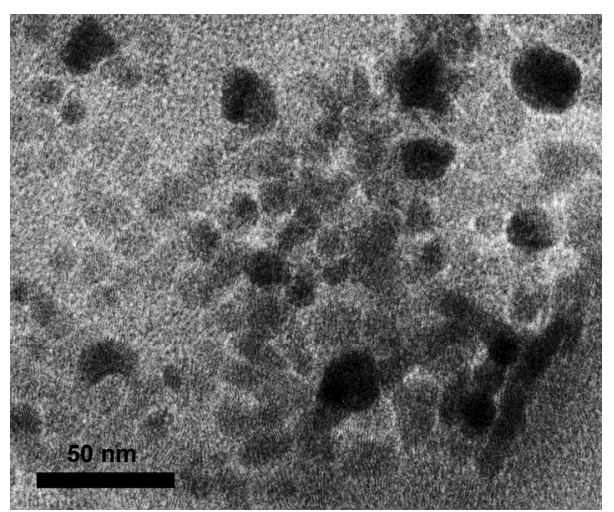

Fig. 1 TEM image of Ag NPs

\subsection{Effects of Ag on root elongation during the seed germination stage}

Both $\mathrm{Ag}$ NPs and $\mathrm{Ag}^{+}$were toxic to cucumber and wheat plants at high exposure concentrations (Fig. 2). At the same concentrations, the plants were more sensitive to the effects of $\mathrm{Ag}^{+}$than $\mathrm{Ag}$ NPs. Interestingly, $\mathrm{Ag} \mathrm{NPs}$ and $\mathrm{Ag}^{+}$showed stimulatory effects on root elongation of cucumber at low concentrations. Similar results have been reported previously. Wang et al. (2013) found that all forms of Ag (NPs and $\mathrm{Ag}^{+}$) were toxic to Arabidopsis and Populus above a specific concentration, but a stimulatory effect was observed on root elongation, fresh weight, and evapotranspiration of both plants at sub-lethal concentrations. They attributed this response to hormesis, a biphasic dose response in which the presence of low doses of toxicants can activate repair mechanisms to overcompensate for the exposure. However, in this study, it seems that the hormesis effects of $\mathrm{Ag}$ NPs and $\mathrm{Ag}^{+}$were species-specific because no significant stimulatory effects on the root elongation of wheat were observed at all the exposure concentrations. 

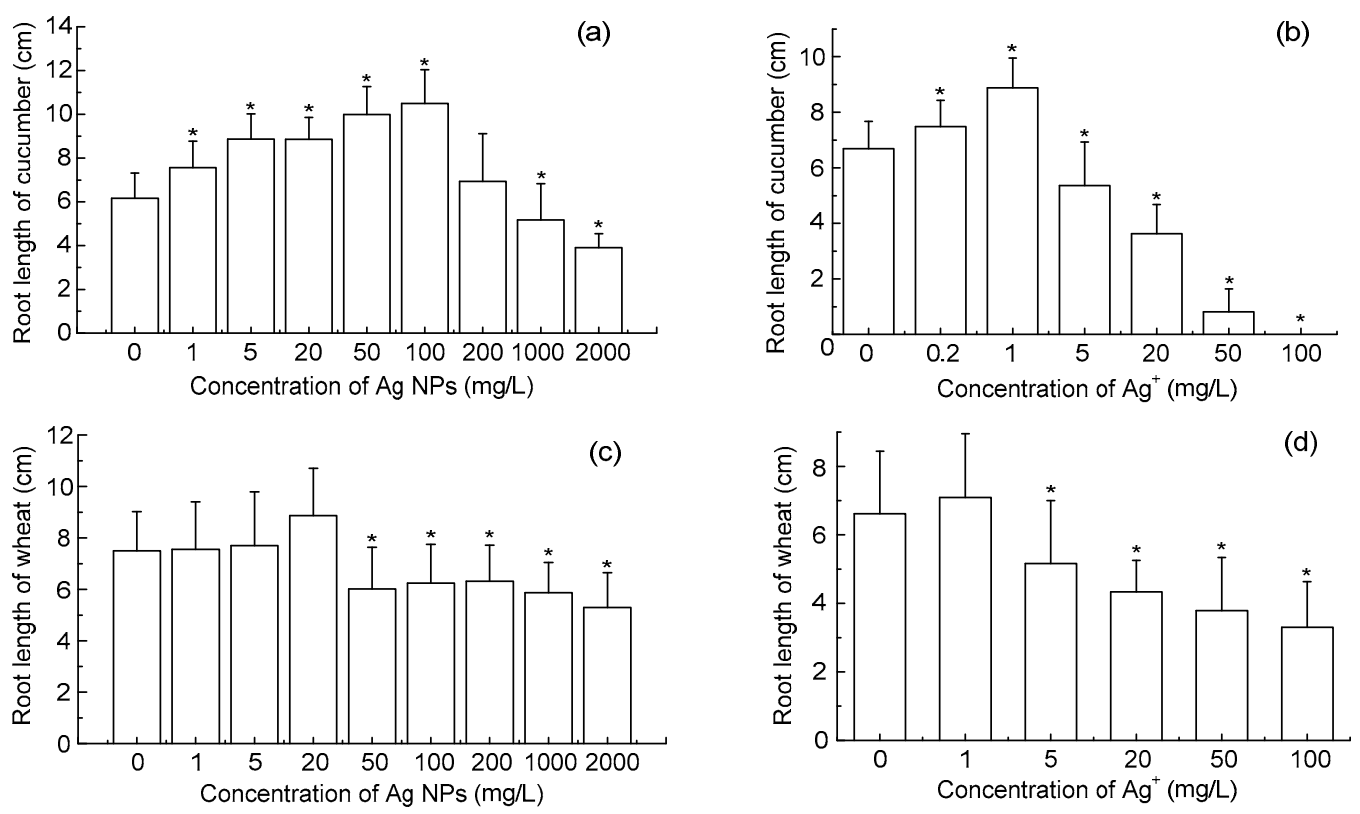

Fig. 2 Effects of $\mathrm{Ag} \mathrm{NPs}$ and $\mathrm{Ag}^{+}$on the root elongation of cucumber and wheat after 5-d exposure at the germination stage

(a) Ag NPs on cucumber; (b) $\mathrm{Ag}^{+}$on cucumber; (c) $\mathrm{Ag}$ NPs on wheat; (d) $\mathrm{Ag}^{+}$on wheat. Data are given as mean $\pm \mathrm{SD}$. ${ }^{*} P<0.05$ vs. control

\subsection{Effects of Ag NPs on biomass during the veg- etative period}

The phytotoxicity of Ag NPs on cucumber and wheat during the vegetative period was evaluated at concentrations of $1,5,20,50$, and $100 \mathrm{mg} / \mathrm{L}$. The dry biomasses of cucumber roots were remarkably reduced by Ag NPs at 50 and $100 \mathrm{mg} / \mathrm{L}$ after three weeks treatment compared with the control $(P<0.05)$ (Fig. 3a). Cucumber shoots were less sensitive to Ag NPs than the roots, and no significant inhibitive effects were observed $(P>0.05)$. As for wheat, Ag NPs significantly decreased the dry biomass of shoots at high concentrations $(20-100 \mathrm{mg} / \mathrm{L})$ but showed no significant effects on the dry biomass of roots $(P>0.05)$ (Fig. 3b). Similar effects were observed for polar, with the leaf and stem biomass being restrained by $\mathrm{Ag}^{+}$but having no effect on the root (Wang et al., 2013). The inhibition thresholds and degrees at this stage are both different from those at the germination stage, indicating that the susceptibility to toxic compounds of a plant is growth stage dependent. Longer time exposure to NP suspensions during the vegetative period than the germination stage might be another reason, which implied that NPs need a longer period to affect plant growth. Thus, the impact of NPs on plant growth may require a relatively long exposure time to determine sublethal effects (Gubbins et al., 2011).

\section{$3.4 \mathrm{Ag}^{+}$released in solution}

Rhizosphere mucilage and root exudates, such as organic acids and amino acids, could promote the adsorption of NPs on the root surface and bring about NPs dissolution, oxidation, or reduction (Cañas et al., 2008; Lin and Xing, 2008). Toxicity of the dissolved form might be a possible mechanism for the toxicity of metal-based NPs, including $\mathrm{Ag}, \mathrm{Ni}, \mathrm{Cu}, \mathrm{ZnO}$, and $\mathrm{La}_{2} \mathrm{O}_{3}$ (Limbach et al., 2007; Griffitt et al., 2008; Miao et al., 2009; Ma et al., 2011). $\mathrm{Ag}^{+}$is known to alter the perception and/or responses to phytohormones and further to affect plant growth (Zhao et al., 2002; Binder et al., 2007; Strader et al., 2009). Recently, toxicity of Ag NPs has been frequently attributed, at least in part, to the release of $\mathrm{Ag}^{+}$at the surface of NPs (Pal et al., 2007; Navarro et al., 2008; Miao et al., 2009). To assess the role of released $\mathrm{Ag}^{+}$, we first measured the dissolution of Ag NPs in exposure solutions, both at the end of the seed germination stage and vegetative period. After 5-d exposure 

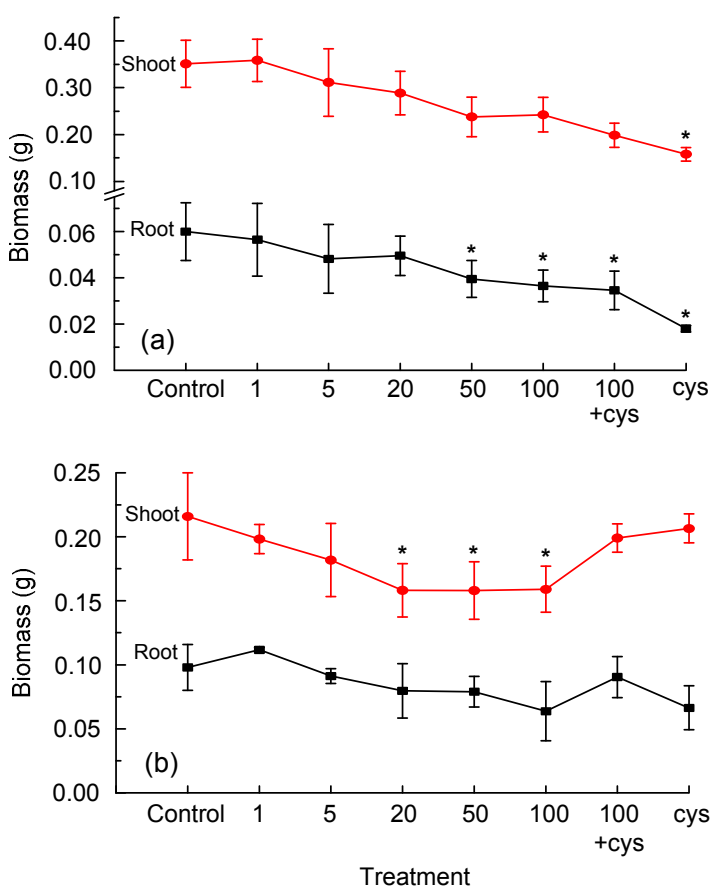

Fig. 3 Effects of Ag NPs, Ag NPs+cysteine, and cysteine on the dry biomasses of root and shoot of cucumber (a) and wheat (b) after three weeks exposure during the vegetative period

Treatment: 1, 5, 20, 50, and 100 are the Ag NPs in mg/L; $100+$ cys is the $100 \mathrm{mg} / \mathrm{L} \mathrm{Ag} \mathrm{NPs}+112 \mathrm{mg} / \mathrm{L}$ cysteine; cys is the $112 \mathrm{mg} / \mathrm{L}$ cysteine. Data are given as mean $\pm \mathrm{SD}$. ${ }^{*} P<0.05$ vs. control

of $1-1000 \mathrm{mg} / \mathrm{L}$ of Ag NPs at the germination stage for cucumber and wheat, the released $\mathrm{Ag}^{+}$into the hydroponic solution was about 2-167 and 0.7$60 \mu \mathrm{g} / \mathrm{L}$, respectively (Figs. 4a and 4b). That is about $0.03 \%$ of Ag NPs dissolved into the hydroponic solution of cucumber, two folds more than that of wheat The difference in dissolution quantities of the two plant species may be attributed to the more developed root systems and the subsequent larger root surface areas of the cucumber than those of the wheat. It is worth noting that, $\mathrm{Ag}^{+}$concentrations in the solutions for vegetative toxic tests were about two times more than the germination stage, $4-103 \mu \mathrm{g} / \mathrm{L}$ for cucumber and $2-41 \mu \mathrm{g} / \mathrm{L}$ for wheat (Figs. $4 \mathrm{c}$ and $4 \mathrm{~d}$ ), respectively. This is probably because of the larger root surface, larger quantity of root exudates, and longer interaction time between the Ag NPs and the root exudates during the vegetative period compared to the germination stage, so the more $\mathrm{Ag}^{+}$released seemed to be inevitable.
The phytotoxicity induced by the released $\mathrm{Ag}^{+}$ after 5-d treatment during the germination stage was explored. Exposure to Ag NPs at $1000 \mathrm{mg} / \mathrm{L}$ (including $0.160 \mathrm{mg} / \mathrm{L}$ of released $\mathrm{Ag}^{+}$in the hydroponic solution) significantly decreased the root elongation of cucumber (Fig. 2a). Yet exposure to $\mathrm{Ag}^{+}$alone at $0.2 \mathrm{mg} / \mathrm{L}$, which is similar to the concentration of $\mathrm{Ag}^{+}$ released by $1000 \mathrm{mg} / \mathrm{L} \mathrm{Ag} \mathrm{NPs,} \mathrm{had} \mathrm{a} \mathrm{stimulatory}$ effect (Fig. 2b). Similarly, the root growth of wheat was dramatically inhibited by the presence of Ag NPs at $1000 \mathrm{mg} / \mathrm{L}\left(60 \mu \mathrm{g} / \mathrm{L}\right.$ released $\left.\mathrm{Ag}^{+}\right)$(Fig. 2c), but the measured $\mathrm{Ag}^{+}$in these hydroponic solutions was too low to account for the observed inhibiting effects. Similar phenomenon was observed by Wang et al. (2013). Superficially, some NP-specific effects were likely to exert. However, an important fact herein seemed to be ignored that the $\mathrm{Ag}^{+}$ion concentrations in the rhizosphere solutions might be higher than that in the exposure solutions. Ag NPs were adsorbed on the root surface with the aid of mucilage and there is an imbalance between oxidation and reduction in the microenvironment named rhizosphere. The concentration of released $\mathrm{Ag}^{+}$we measured in the culture suspensions (with plants cultured) could be far less than that on the root surfaces. The nano-bio interface was the main location of the dissolution. Zhang et al. (2012) found that concentrations of $\mathrm{Yb}^{3+}$ in the rhizosphere solutions were indeed higher than that in the exposure solutions.

The dissolution of Ag NPs in the culture medium, as well as the possible formation of NPs from $\mathrm{Ag}^{+}$on root surfaces makes it difficult to differentiate ionic effects from NP-specific effects (Gardea-Torresdey et al., 2003; Geisler-Lee et al., 2013). As a strong $\mathrm{Ag}^{+}$ chelating ligand, cysteine has been proven to be useful in examining the contribution of $\mathrm{Ag}^{+}$to the overall toxicity of Ag NPs (Navarro et al., 2008). Thus, the role of $\mathrm{Ag}^{+}$in determining the phytotoxicity of Ag NP suspensions was assessed in the presence of cysteine. The complete abolishment of the impact on the root elongation at the germination stage by cysteine indicated that the protective effects of cysteine were due to its chelating with $\mathrm{Ag}^{+}$in the exposure media, which resulted in a reduced Ag bioavailability (Fig. 5). Similar phenomenon appeared after three weeks of exposure at the vegetative period of the cucumber, when cysteine completely eliminated the inhibition of $100 \mathrm{mg} / \mathrm{L}$ of $\mathrm{Ag}$ NPs on the biomass 
(cysteine alone did not show any significant effect) (Fig. 3b). As for the cucumber, cysteine alone reduced the biomass possibly because of the high sensitivity to cysteine (Fig. 3a). However, cysteine still somewhat alleviated the toxicity of $100 \mathrm{mg} / \mathrm{L}$ of $\mathrm{Ag}$ NPs to the biomass of the cucumber. This strongly
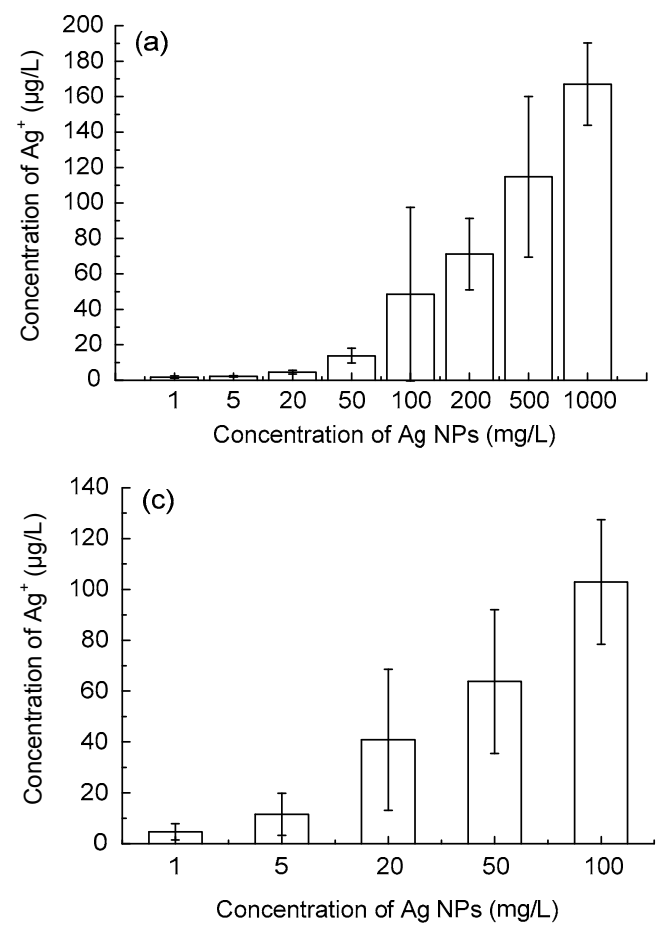

emphasized the fact that Ag NPs contributed to the toxicity by serving as a source of $\mathrm{Ag}^{+}$. He et al. (2012) discovered that cysteine completely removed the inhibitory effects of Ag NPs on the metabolic activity of Chattonella marina, which suggested that the toxicity of Ag NPs was due to the release of $\mathrm{Ag}^{+}$.

Fig. 4 Free ion concentrations in exposure solutions of Ag NPs at different stages After 5-d treatment of Ag NPs at the germination stage of cucumber (a) and wheat (b); after 3-week treatment of Ag NPs during the vegetative period of cucumber (c) and wheat (d). Data are given as mean $\pm \mathrm{SD}$
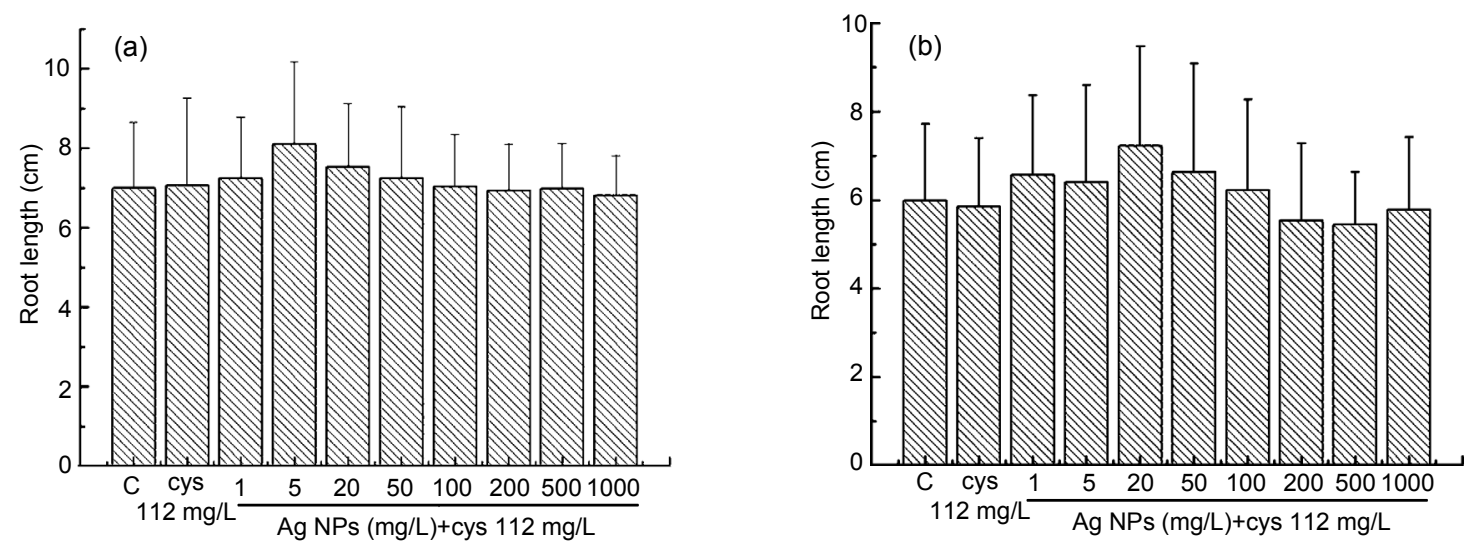

Fig. 5 Effect of cysteine on the root elongation of cucumber (a) and wheat (b) after 5-d exposure of Ag NPs at the germination stage

C: control. Data are given as mean \pm SD. Pure cysteine $(112 \mathrm{mg} / \mathrm{L})$ did not show any effect on root elongation $(P>0.05)$ 


\subsection{Uptake and translocation of Ag NPs in cu- cumber and wheat}

TEM images of the cross sections of cucumber and wheat roots after 3-week exposure of $100 \mathrm{mg} / \mathrm{L}$ Ag NPs are shown in Fig. 6. In contrast to the control (Figs. 6a and 6c), high electron-dense deposits can be found in the cell wall and cytoplasm in sections of $100 \mathrm{mg} / \mathrm{L} \mathrm{Ag} \mathrm{NPs} \mathrm{treated} \mathrm{groups} \mathrm{(Figs.} \mathrm{6b} \mathrm{and} \mathrm{6d).}$
Ag contents in cucumber and wheat tissues after three weeks treatments of Ag NPs are shown in Fig. 7. Total Ag contents increased with the increasing concentrations of Ag NPs in the exposure solutions. The majority of $\mathrm{Ag}$ was accumulated in the roots. Translocation factors (TFs) of Ag, defined as the Ag content ratio of the shoot to root, were very low $(0.001-0.007)$ in cucumber and wheat with the
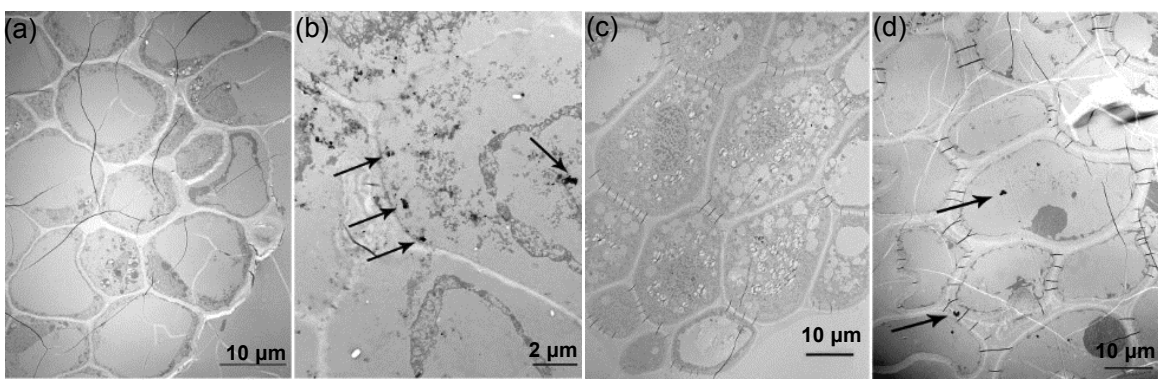

Fig. 6 TEM images of root cross sections from untreated (a) and Ag NP treated (b) cucumber, and untreated (c) and Ag NP treated (d) wheat after three weeks during the vegetative period

Ag NP was treated at $100 \mathrm{mg} / \mathrm{L}$. Arrows indicated Ag-enriched areas
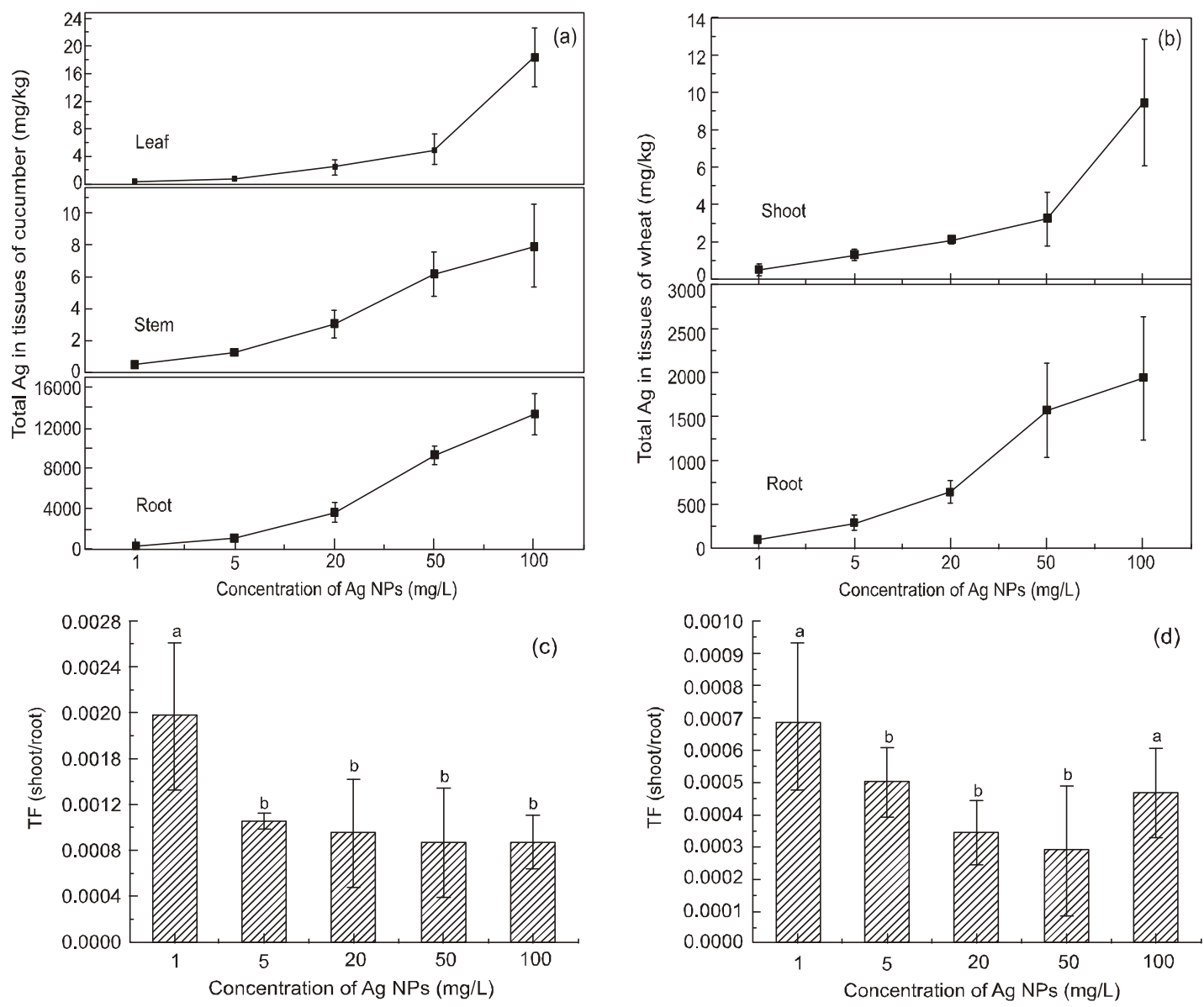

Fig. 7 Ag content in tissues of cucumber (a) and wheat (b) after three weeks of exposure of Ag NPs and the translocation factors (TFs) of Ag in cucumber (c) and wheat (d)

Data are given as mean \pm SD. The same letters above the bars in (c) and (d) were not significantly different $(P>0.05)$ 
treatments of Ag NPs. It seems that only a little Ag NPs or $\mathrm{Ag}^{+}$were transported from the roots to shoots in this study. This might be because most of the Ag NPs were adsorbed on the root surface, and only a little Ag could move into the stele and was available for upward transport. It can be seen that the TF obtained in the cucumber were three times higher than those in wheat (Figs. 7c and 7d). The better transportation capability in cucumber probably resulted from the greater blade area and stronger evaporative power than in wheat.

\section{Conclusions}

Based on total Ag concentrations, it was observed that $\mathrm{Ag}^{+}$displayed stronger effects on cucumber and wheat than Ag NPs at the germination stage. Meanwhile, the same concentration of Ag with different species (Ag NPs or $\mathrm{Ag}^{+}$) exerted different influences between the two stages. Thus, the developmental period of the plant should also be considered when assessing the risks posed by NPs in the environment.

This study revealed the determinant role of dissolved $\mathrm{Ag}^{+}$on the toxicity of $\mathrm{Ag}$ NPs for cucumber and wheat, and the protective effect of cysteine was attributed to its chelation with $\mathrm{Ag}^{+}$. Results of ICP-MS and TEM indicated that Ag (Ag NPs or other forms) could be absorbed by the roots and translocated to the shoots. The low translocation factors of $\mathrm{Ag}$ in the two plants suggested that the movement of $\mathrm{Ag}$ from the roots to shoots was difficult.

\section{References}

AshaRani, P.V., Low Kah Mun, G., Hande, M.P., et al., 2009. Cytotoxicity and genotoxicity of silver nanoparticles in human cells. ACS Nano, 3(2):279-290. [doi:10.1021/ nn800596w]

Benn, T.M., Westerhoff, P., 2008. Nanoparticle silver released into water from commercially available sock fabrics. Environmental Science and Technology, 42(11):41334139. [doi:10.1021/es7032718]

Binder, B.M., Rodriguez, F.I., Bleecker, A.B., et al., 2007. The effects of Group 11 transition metals, including gold, on ethylene binding to the ETR1 receptor and growth of Arabidopsis thaliana. FEBS Letters, 581(26):5105-5109. [doi:10.1016/j.febslet.2007.09.057]

Blaser, S.A., Scheringer, M., MacLeod, M., et al., 2008. Estimation of cumulative aquatic exposure and risk due to silver: contribution of nano-functionalized plastics and textiles. Science of The Total Environment, 390(2-3): 396-409. [doi:10.1016/j.scitotenv.2007.10.010]
Bozzola, J.J., Russell, L.D., 1999. Electron Microscopy: Principles and Techniques for Biologists. Jones \& Bartlett Learning.

Cañas, J.E., Long, M., Nations, S., et al., 2008. Effects of functionalized and nonfunctionalized single-walled carbon nanotubes on root elongation of select crop species. Environmental Toxicology and Chemistry, 27(9):19221931. [doi:10.1897/08-117.1]

Choi, O., Hu, Z., 2008. Size dependent and reactive oxygen species related nanosilver toxicity to nitrifying bacteria. Environmental Science and Technology, 42(12):45834588. [doi:10.1021/es703238h]

Gardea-Torresdey, J.L., Gomez, E., Peralta-Videa, J.R., et al., 2003. Alfalfa sprouts: a natural source for the synthesis of silver nanoparticles. Langmuir, 19(4):1357-1361. [doi:10. $1021 / 1 a 020835 \mathrm{i}]$

Geisler-Lee, J., Wang, Q., Yao, Y., et al., 2013. Phytotoxicity, accumulation and transport of silver nanoparticles by Arabidopsis thaliana. Nanotoxicology, 7(3):323-337. [doi:10.3109/17435390.2012.658094]

Griffitt, R.J., Luo, J., Gao, J., et al., 2008. Effects of particle composition and species on toxicity of metallic nanomaterials in aquatic organisms. Environmental Toxicology and Chemistry, 27(9):1972-1978. [doi:10.1897/08002.1]

Gubbins, E.J., Batty, L.C., Lead, J.R., 2011. Phytotoxicity of silver nanoparticles to Lemna minor L. Environmental Pollution, 159(6):1551-1559. [doi:10.1016/j.envpol.2011. 03.002]

He, D., Dorantes-Aranda, J.J., Waite, T.D., 2012. Silver nanoparticle algae interactions: oxidative dissolution, reactive oxygen species generation and synergistic toxic effects. Environmental Science and Technology, 46(16): 8731-8738. [doi:10.1021/es300588a]

Hussain, S., Hess, K., Gearhart, J., et al., 2005. In vitro toxicity of nanoparticles in BRL 3A rat liver cells. Toxicology in Vitro, 19(7):975-983. [doi:10.1016/j.tiv.2005.06.034]

Jiang, W., Kim, B.Y., Rutka, J.T., et al., 2008. Nanoparticlemediated cellular response is size-dependent. Nature Nanotechnology, 3(3):145-150. [doi:10.1038/nnano. 2008.30]

Kim, S., Choi, J.E., Choi, J., et al., 2009. Oxidative stressdependent toxicity of silver nanoparticles in human hepatoma cells. Toxicology in Vitro, 23(6):1076-1084. [doi:10.1016/j.tiv.2009.06.001]

Limbach, L.K., Wick, P., Manser, P., et al., 2007. Exposure of engineered nanoparticles to human lung epithelial cells: influence of chemical composition and catalytic activity on oxidative stress. Environmental Science and Technology, 41(11):4158-4163. [doi:10.1021/es062629t]

Lin, D.H., Xing, B.S., 2007. Phytotoxicity of nanoparticles: inhibition of seed germination and root growth. Environmental Pollution, 150(2):243-250. [doi:10.1016/j. envpol.2007.01.016]

Lin, D.H., Xing, B.S., 2008. Root uptake and phytotoxicity of $\mathrm{ZnO}$ nanoparticles. Environmental Science and Technology, 42(15):5580-5585. [doi:10.1021/es800422x]

Ma, Y.H., He, X., Zhang, P., et al., 2011. Phytotoxicity and biotransformation of $\mathrm{La}_{2} \mathrm{O}_{3}$ nanoparticles in a terrestrial 
plant cucumber (Cucumis sativus). Nanotoxicology, 5(4): 743-753. [doi:10.3109/17435390.2010.545487]

Miao, A.J., Schwehr, K.A., Xu, C., et al., 2009. The algal toxicity of silver engineered nanoparticles and detoxification by exopolymeric substances. Environmental Pollution, 157(11):3034-3041. [doi:10.1016/j.envpol.2009. 05.047]

Miao, A.J., Luo, Z., Chen, C.S., et al., 2010. Intracellular uptake: a possible mechanism for silver engineered nanoparticle toxicity to a freshwater alga Ochromonas danica. PLoS ONE, 5(12):e15196. [doi:10.1371/journal. pone.0015196]

Morones, J.R., Elechiguerra, J.L., Camacho, A., et al., 2005. The bactericidal effect of silver nanoparticles. Nanotechnology, 16(10):2346. [doi:10.1088/0957-4484/16/ 10/059]

Navarro, E., Piccapietra, F., Wagner, B., et al., 2008. Toxicity of silver nanoparticles to Chlamydomonas reinhardtii. Environmental Science and Technology, 42(23):89598964. [doi:10.1021/es801785m]

Pal, S., Tak, Y.K., Song, J.M., 2007. Does the antibacterial activity of silver nanoparticles depend on the shape of the nanoparticle? A study of the gram-negative bacterium Escherichia coli. Applied and Environmental Microbiology, 73(6):1712-1720. [doi:10.1128/AEM.02218-06]
Ratte, H.T., 1999. Bioaccumulation and toxicity of silver compounds: a review. Environmental Toxicology and Chemistry, 18(1):89-108. [doi:10.1002/etc.5620180112]

Strader, L.C., Beisner, E.R., Bartel, B., 2009. Silver ions increase auxin efflux independently of effects on ethylene response. The Plant Cell, 21(11):3585-3590. [doi:10. 1105/tpc.108.065185]

Wang, J., Koo, Y., Alexander, A., et al., 2013. Phytostimulation of poplars and Arabidopsis exposed to silver nanoparticles and $\mathrm{Ag}^{+}$at sublethal concentrations. Environmental Science and Technology, 47(10):5442-5449. [doi:10.1021/es4004334]

Yin, L., Cheng, Y., Espinasse, B., et al., 2011. More than the ions: the effects of silver nanoparticles on Lolium multiflorum. Environmental Science and Technology, 45(6): 2360-2367. [doi:10.1021/es103995x]

Zhang, P., Ma, Y.H., Zhang, Z.Y., et al., 2012. Comparative toxicity of nanoparticulate/bulk $\mathrm{Yb}_{2} \mathrm{O}_{3}$ and $\mathrm{YbCl}_{3}$ to cucumber (Cucumis sativus). Environmental Science and Technology, 46(3):1834-1841. [doi:10.1021/es2027295]

Zhao, X.C., Qu, X., Mathews, D.E., et al., 2002. Effect of ethylene pathway mutations upon expression of the ethylene receptor ETR1 from Arabidopsis. Plant Physiology, 130(4):1983-1991. [doi:10.1104/pp.011635]

\section{中文概要:}

\section{本文题目: 纳米银对黄瓜和小麦的毒性效应研究}

Phytotoxicity of silver nanoparticles to cucumber (Cucumis sativus) and wheat (Triticum aestivum)

研究目的: 研究纳米银对黄瓜和小麦的毒性及在植物中的转运和分布, 探讨其毒性机制, 为纳米银的环 境风险评估提供科学依据。

创新要点: 1. 选取单子叶和双子叶植物为对象, 比较研究纳米银对其萌发阶段和生长阶段的毒性效应及 其影响因素; 2. 多数研究中的纳米银均有表面修饰, 本研究选择无表面修饰的纳米银材料, 排除表面活性剂的干扰因素; 3. 以络合剂半胱氨酸掩蔽解离出的银离子，探讨纳米银颗粒对 植物毒性的贡献。

研究方法: 通过植物根长 (图 2) 和生物量 (图 3) 分别评价萌发和生长阶段纳米银的植物毒性。利用 电感耦合等离子体质谱（ICP-MS）测定植物组织银元素的含量（图 7)。通过组织切片，利 用透射电镜（TEM）观察植物根中银的微观分布（图 6)。通过在暴露介质中添加半胱氨酸 掩蔽银离子来评价纳米银颗粒对植物毒性的贡献 (图 3 和 5 )。

重要结论: 在较高暴露浓度情况下, 纳米银和银离子对小麦和黄瓜都具有明显的毒性。但当纳米银浓度 低于 $200 \mathrm{mg} / \mathrm{L}$, 银离子浓度低于 $5 \mathrm{mg} / \mathrm{L}$ 时, 两者均能促进黄瓜根系的生长。两种植物在营 养生长阶段比萌发阶段对纳米银的毒性更敏感。纳米银暴露后, 银首先积聚于植物的根, 然 后被转移到地上部。为评价纳米银释放的银离子的作用，我们测定了暴露后介质中银离子的 浓度。在种子萌发阶段, 黄瓜和小麦的暴露液中约 $0.03 \%$ 和 $0.01 \%$ 的纳米银溶解, 而在营养 生长阶段, 溶解的纳米银达到 $0.17 \%$ 和 $0.06 \%$ 。半胱氨酸作为银离子的强络合剂, 能够彻底 消除纳米银对黄瓜和小麦的作用, 说明纳米银的植物效应可能来自于其释放的银离子。

关键词组: 纳米银; 银离子; 黄瓜; 小麦; 植物毒性 